\title{
Determinants of gingival recessions in Portuguese adults
}

\author{
João Lapa ${ }^{a}$, Nélio J. Veiga ${ }^{a}$, Claudia Ribeiro ${ }^{a}$, Tiago Marques ${ }^{a}$, Nuno Malta Santos ${ }^{a}$, Manuel de Sousa ${ }^{a}$
}

\begin{abstract}
Objectives: The objective of this study consisted in determining the prevalence of gingival recession and potential risk factors associated in a sample of patients that had a dental appointment in the University Clinic of the Portuguese Catholic University in Viseu, Portugal.

Methods: We conducted an epidemiological observational cross-sectional study where a sample of 101 patients was assessed. The participants were subjected to a questionnaire and an intra-oral clinical examination was made in order to assess gingival recessions.

Results: The prevalence of recession was $85.1 \%$. The presence of habits and a high plaque index are associated with the onset of recessions and its severity. The aesthetic condition was influenced only in $14.0 \%$ of the cases and just $17.4 \%$ of the patients with gingival recession had tooth hipersensibility. There is a stronger association between the development of recessions and using a brushing technique based mostly on horizontal movements and brushes with harder bristles.

Conclusion: Although further studies need to be applied in a more representative sample, we conclude that the majority of the analyzed sample has already suitable oral health behaviors, however, some need to be modified as the understanding of the need to change certain habits to prevent development of recessions.
\end{abstract}

Key words: Gingival recession; Prevalence; Toothbrushing; Orthodontic treatment; Dental plaque

\section{Determinantes da recessão gengival em adultos portugueses}

\section{RESUMO}

Objetivos: O objetivo deste estudo consistiu em determinar a prevalência de recessões gengivais e fatores de risco associados numa amostra de pacientes que tiveram uma consulta odontológica na Clínica Universitária da Universidade Católica Português em Viseu, Portugal.

Metodologia: Foi realizado um estudo epidemiológico observacional transversal onde uma amostra de 101 pacientes foi avaliada. Os participantes foram submetidos a um questionário e um exame clínico intra-oral foi realizado.

Resultados: A prevalência de recessões gengivais foi de $85,1 \%$. A presença de hábitos e um elevado índice de placa estão associados com o aparecimento de recessões e a sua gravidade. A condição estética foi influenciada apenas em $14,0 \%$ dos casos e apenas $17,4 \%$ dos pacientes com recessão gengival tinha hipersensibilidade dentária. Há uma forte associação entre o desenvolvimento de recessões em casos de utilização de uma técnica de escovagem com base em movimentos horizontais e escovas com cerdas mais duras.

Conclusão: Embora devem ser realizados estudos com uma amostra mais representativa, podemos concluir que a maior parte da amostra analisada tem comportamentos de saúde oral adequados, no entanto, alguns devem ser modificados como a compreensão da necessidade de alterar certos hábitos para prevenir o desenvolvimento de recessões.

Palavras-chave: Recessão gengival; Prevalência; Escovagem; Tratamento ortodôntico; Placa bacteriana a Health Sciences Department, Universidade Católica Portuguesa, Viseu, Portugal
Correspondence: Nélio J. Veig nelioveiga@gmail.com

Received: April 13, 2014 Accepted: October 10, 2016

Conflict of Interests: The authors state that there are no financial and personal conflicts of interest that could have inappropriately influenced their work.

Copyright: @ 2016 Lapa et al licensee EDIPUCRS.

This work is licensed under a Creative Commons Attribution 4.0 International License. 


\section{INTRODUCTION}

Gingival recession is a clinical condition defined as the attachment loss that results in migration of the free gingival margin of any tooth surface in the apical direction in relation to the cement-enamel junction (CEJ), which is concomitant with root exposure to the oral environment [1-7].

This condition is often seen as having a multifactorial origin being the result of a combination of factors, however there are cases, which have no clinical evident ethiology (17\%) [8-14].

There is agreement regarding the increased prevalence, extent and severity of gingival recession with age $[1,3,4$, 6,7,10-12].

In younger patients recessions that seem to appear are usually located, which suggests the existence of isolated ethiologic factors. In patients with advanced age, the distribution of recessions appears to be more widespread, which seems to be related to the cumulative effect of other factors such as periodontal disease [10].

As for gender, there are studies in which women appear to be the group with the better oral health status and therefore a greater prevalence of recessions, as the studies of Furlan et al. and Chrysanthakopoulos et al. seem to prove $[2,10,11]$.

However, other epidemiological studies, such as Slutzkey and Levin argue that male gender have a higher prevalence of recessions [ $[1,4,7,12]$.

The ethnic race is also considered as being an important determinant for gingival recessions when associated with periodontal disease. Susie et al. found that non-caucasian subjects had a higher risk of developing periodontal pockets equal or higher than $5 \mathrm{~mm}$ than the caucasians [13].

The association between the development of recessions and a brushing technique based on horizontal movements or the trauma caused by the toothbrush in regions where there is a low rate of plaque has been widely supported [6,9,14-17].

There are other important factors as the brushing duration, frequency, the force exerted on the brush, the hardness of the bristles of the brush, the brushing technique and frequency that the brush change is made, that are considered determinants associated with the higher risk of gingival recessions presence [15].

The marginal gingival tissue inflammation induced by the accumulation of plaque is another factor directly related to the development of gingival recessions [1-3,5-7,9,11,18,19].

Another important factor is the periodontal treatment, which can result in recessions. The decrease of gingival inflammation may lead to the contraction of the gingival tissues $[1,9,10]$.

Several authors argue that the dental fillings with subgingival margins can be the cause of many recessions due to plaque accumulation, gingival inflammation and bone loss $[1,2,6,20,21]$.

The development of recessions is strongly associated with the absence of alveolar bone site $[1,2,4-6,8,9,12]$. Kassab and Cohen claim that "fenestration and dehiscence of the alveolar bone, abnormal position of the tooth in the arch, the abnormal tooth eruption and the individual form of the tooth" are anatomical factors that may result in a thinner cortical bone and in a more susceptible cortical bone resorption $[1,3,5,6,9,12]$.

The fact that the patient has already undergone previous orthodontic treatment seems to be correlated with the presence, extent and severity of the recession $[4,6,22]$.

Another relevant topic to some authors is the fact that the oclusal trauma isn't able to induce periodontal tissue destruction, however, it may lead to bone resorption and thus the increased tooth mobility [23].

In 2008 a study was conducted to determine the relation between the presence of tooth mobility (indicative of oclusal trauma) and the development of recession. It was found that $34.6 \%$ of patients who had gingival recession also had tooth mobility compared to $7.8 \%$ of the patients who had no recession. Thus, the probability of developing gingival recession in teeth with mobility is 6.2 times higher than in teeth without mobility. This correlation between the recession and oclusal trauma had been advocated earlier by Stillman and he had already described the typical recession in the presence of oclusal interferences as narrow slits in a triangular shape on the buccal surface of the gum that covers the teeth [24].

The practice of body piercing has been associated with recessions in the lower incisors (mostly central) on the lingual surface in lingual piercings and in the buccal surface in lip piercings [25].

There is also a relationship between the presence of recessions in smoking patients without periodontal disease. In smoking patients, gingival recessions are more located on the buccal surfaces of the maxillary molars and premolars and in the mandibular central incisors and premolars [1].

The high insertion of the labial fraenum and/or muscle insertion are anatomical conditions also referred to as etiological factors of the recession $[1,2,4,6,8,9]$.

In a study conducted in 1993 there was found that "type 1 diabetics with poor glycaemic control (...) had worse gingival index, probing higher postpartum haemorrhage, further loss of adhesion and higher interproximal bone and gingival recession" [26].

Rheumatoid arthritis is a systemic autoimmune disease characterized by inflammation of the articular surfaces, ending in the destruction of cartilage and subchondral bone. This may affect the temporomandibular joint, but also have other manifestations such as periodontal disease and all of its manifestations from bleeding on probing to loss of attachment and appearance of recessions [27].

Some authors argue that bulimia, understood as "obsessive and massive intake of food followed by selfinduced vomiting, prolonged fasting volunteer through the abuse of laxatives and/or diuretics" to have this action caused by the constant habit of vomiting, may cause chemical trauma in gingival tissues resulting in recessions. However, others argue that this relationship is not significant $[28,29]$.

The objective of this study consisted in determining the prevalence of gingival recession and potential risk 
factors associated in a sample of patients that had a dental appointment in the University Clinic of the Portuguese Catholic University in Viseu (UCP-Viseu), Portugal.

\section{METHODS}

This study was designed as an observational crosssectional epidemiological study. We obtained a sample of 101 individuals who respected the criteria for inclusion in the sample, which were:

- Patients who have a dental appointment at the University Clinic of UCP-Viseu, Portugal;

- Patients with age between 20 and 30 years old;

- Patients with permanent teeth disregarding the presence or absence of third permanent molars;

- Patients who have at least 20 teeth in the oral cavity because otherwise, the small number of teeth could directly interfere with the results of this study;

- Patients without fixed orthodontic appliances.

At the beginning, the patients were informed of the intention of the study and signed the Informed Consent. Then proceeded to the interview. Finally, patients were subjected to an intraoral exam to obtain data on the O'Leary Plaque Index and Gingival Recession Index and, consequently, the observer filled the data on the record sheet.

For intraoral examination we used gloves and mask for individual protection, paper napkins, intraoral mirror, periodontal probe (recommended by the World Health Organization), bib and bib holder, air/water syringe, microbrush, dental plaque revealer (red erythrosine), contraangle, polishing brush and polishing paste.

To determine the O'Leary index percentage the plaque revealer (erythrosine) was applied in all dental surfaces in order to determine the value of the O'Leary Plaque Index.

Then, during the intraoral examination, the observer calculated the values of the existing gingival recessions using the Smith classification, since it is the most widely used system of classification for statistical studies. The classification scheme presented by Smith to the vertical extent of gum recession is shown in Table 1.

We used the Statistical Package for Social Sciences (SPSS $20.0 \mathrm{Mac}^{\mathrm{OS}}{ }^{\circledR}$ ) in order to process and analyze the data collected from all variables. Through SPSS $20.0^{\circledR}$, the continuous variables were described using measures of central tendency (mean) and measures of dispersion (standard deviation). We calculated prevalences that were expressed in percentages. To compare the proportions we used the Chi-square Test.

Table 1. Smith Classification for vertical extension (1997).

\begin{tabular}{|c|c|}
\hline Score & Criteria \\
\hline 0 & No clinical evidence of root exposure \\
\hline 1 & $\begin{array}{l}\text { No clinical exposure of root exposure but a subjective } \\
\text { awareness of dentinal hypersensitivity is reported, and/or } \\
\text { there is clinically detectable exposure of the CEJ not extending } \\
\text { more than } 1 \text { millimeter vertically to the gingival margin }\end{array}$ \\
\hline $2-8$ & $\begin{array}{l}\text { Root exposure } 2 \text { to } 8 \mathrm{~mm} \text { extending vertically from the CEJ } \\
\text { to the base of the soft-tissue defect }\end{array}$ \\
\hline 9 & $\begin{array}{l}\text { Root exposure more than } 8 \mathrm{~mm} \text { from the CEJ to the base } \\
\text { of the soft-tissue defect }\end{array}$ \\
\hline * & $\begin{array}{l}\text { An asterisk is afficed to the second digit whenever the } \\
\text { vertical componente of the soft-tissue defect encroaches in } \\
\text { the mucogingival juntion or extends beyond it into alveolar } \\
\text { mucosa. The absence of an asterisk implies either absence } \\
\text { of mucogingival juntion involvemnt at the indexed site or } \\
\text { its non-involvement in the soft-tissue defect }\end{array}$ \\
\hline
\end{tabular}

\section{RESULTS}

In this study, the sample used consisted of 101 subjects, $47(46.5 \%)$ individuals belonging to the male gender and 54 $(53.5 \%)$ belonging to the female gender. Regarding age, we obtained an average of $23.11 \pm 2.23$ years, with a minimum age of 20 years and found maximum of 29 years.

The prevalence of gingival recession was determined to $85.1 \%$ corresponding to the 86 subjects observed.

In Table 2, we found that when the value of the Plaque Index was between 75 and $100 \%$, all patients had gingival recession, while at lower values there were higher amount of individuals without gingival recession. However, these values were much lower than those corresponding to the cases where gingival recession was present.

In Table 3 we have can verify that $45.5 \%$ of patients brush 2 times per day their teeth and have gingival recession, and that there wasn't any individual who brushed their teeth once a day without any recession. The value of subjects without gingival recession increases if they brushed their teeth two or more times a day.

Table 2. Relation between Plaque Index Value ande the presence of gingival recession.

\begin{tabular}{|c|c|c|c|c|c|c|c|}
\hline & & & Gingi & sion & & & \\
\hline & & & & & & & \\
\hline & & $N$ & $\%$ & $\mathrm{~N}$ & $\%$ & $N$ & $\%$ \\
\hline & $0-24 \%$ & 32 & $31,7 \%$ & 9 & $8,9 \%$ & 41 & $40,6 \%$ \\
\hline Value of Plague Indey & $25-49 \%$ & 41 & $40,6 \%$ & 5 & $5,0 \%$ & 46 & $45,5 \%$ \\
\hline & $50-74 \%$ & 8 & $7,9 \%$ & 1 & $1,0 \%$ & 9 & $8,9 \%$ \\
\hline & $75-100 \%$ & 5 & $5,0 \%$ & 0 & $0,0 \%$ & 5 & $5,0 \%$ \\
\hline Total & & 86 & $85,1 \%$ & 15 & $14.9 \%$ & 101 & $100.0 \%$ \\
\hline
\end{tabular}


We found that $46.5 \%$ of patients used brushes with medium bristles and only $6.9 \%$ didn't show any gingival recession.

In Table $4,56.4 \%$ of the patients said they mostly use a circular brushing technique, however, $43.6 \%$ had gingival recession.

We found $24.4 \%$ of patients had gingival recession related to occlusal trauma. The malposition of the teeth was also associated with the presence of gingival recession and we can verify that $31.4 \%$ of subjects had malpositioned teeth with gingival recession present simultaneously.

Etiological factors such as alveolar bone deficiency and abnormal insertion brake may be associated with the presence of gingival recession and these ratios are respectively presented in Table 5 and Table 6 .

The presence of gingival recessions after previous orthodontic treatment was also assessed and the presence of habits and their relationship to the development of this condition was also evaluated. About $30.7 \%$ of patients with gingival recession had already undergone previous orthodontic treatment and 5.9\% had undergone previous orthodontic treatment but had no gingival recession. In Table 12, about $19.8 \%$ had gingival recession and presented both habits, $25.7 \%$ drunk alcohol and had recessions and finally $5.9 \%$ smoked and also had recessions.

Table 3. Relation between the brushing frequency and the presence of gingival recessions.

\begin{tabular}{|c|c|c|c|c|c|c|c|}
\hline & & & Gingi & sion & & & \\
\hline & & & & & & & \\
\hline & & $\mathrm{N}$ & $\%$ & $\mathrm{~N}$ & $\%$ & $\mathrm{~N}$ & $\%$ \\
\hline & 1 per day & 14 & $13,9 \%$ & 0 & $0,0 \%$ & 14 & $13,9 \%$ \\
\hline Brushing Frequency & 2 per day & 46 & $45,5 \%$ & 6 & $5,9 \%$ & 52 & $51,4 \%$ \\
\hline & More than 2 per day & 26 & $25,7 \%$ & 9 & $8,9 \%$ & 35 & $34,7 \%$ \\
\hline Total & & 86 & $85,1 \%$ & 15 & $14,9 \%$ & 101 & $100,0 \%$ \\
\hline
\end{tabular}

Table 4. Relation between types of brushing movements and the presence of gingival recessions.

\begin{tabular}{|c|c|c|c|c|c|c|c|}
\hline & & & Gingi & sion & & & \\
\hline & & & & & & & \\
\hline & & $\mathrm{N}$ & $\%$ & $\mathrm{~N}$ & $\%$ & $\mathrm{~N}$ & $\%$ \\
\hline & Horizontal & 36 & $33,6 \%$ & 1 & $1,0 \%$ & 37 & $36,6 \%$ \\
\hline $\begin{array}{l}\text { Most common Brushing } \\
\text { tecnhique used }\end{array}$ & Vertical & 6 & $5,9 \%$ & 1 & $1,0 \%$ & 7 & $6,9 \%$ \\
\hline & Circular & 44 & $43,6 \%$ & 13 & $12,9 \%$ & 57 & $56,4 \%$ \\
\hline Total & & 86 & $85,1 \%$ & 15 & $14,9 \%$ & 101 & $100,0 \%$ \\
\hline
\end{tabular}

Table 5. Relation between the presence of alveolar bone loss and the presence of gingival recession

\begin{tabular}{llcc}
\hline \multirow{2}{*}{ Alveolar bone defect } & & N & $\%$ \\
\cline { 2 - 4 } & Present & 2 & $2,3 \%$ \\
\cline { 2 - 4 } Total & Absent & 84 & $97,7 \%$ \\
\hline
\end{tabular}

Table 6. Relation between abnormal frenum insertion and the presence of gingival recession.

\begin{tabular}{llcc}
\hline & & N & $\%$ \\
\cline { 2 - 4 } Abnormal frenum & Present & 2 & $2,3 \%$ \\
insertion & Absent & 84 & $97,7 \%$ \\
\hline Total & & 86 & $100,0 \%$ \\
\hline
\end{tabular}

\section{DISCUSSION}

To avoid the cumulative effects of age reported by many authors, we have chosen a sample that included an age range between 20 and 30 years old $[1,3,4,6]$.

Regarding gender, in this study we didn't find relevant data to indicate a more favorable gender for the development of recessions, because we did not obtain significant statistical differences $(p=0.27)$, which is advocated by some studies $[7,10]$.

On what concerns with the frequency of brushing we obtained statistically significant differences $(p=0.01)$, verifying that all the patients that only brushed their teeth once a day showed recession, possibly due to the lower hygiene. However, with the increase in the number of 
daily brushes, there is also an increase of individuals and an increase in patients presenting recessions. As in other studies, we found that about $36.6 \%$ of the patients used mainly horizontal brushing techniques. Of these, only one person had no recessions $(\mathrm{p}=0.01)[5,9]$.

Several studies argue the correlation between the presence of plaque and the development of recessions. In this study, although we did not find statistical significant differences, we verified that all patients with Plaque Index between $75 \%$ and $100 \%(5.0 \%)$ had recessions and the others, with lower levels of Plaque Index, had less recessions $[5,7,11]$.

About $24.4 \%$ of patients with recessions showed similar results to those described by Stillman when associated occlusal trauma [24].

As for a bad tooth position, $31.4 \%$ of patients with recession had badly positioned teeth with recessions associated, which is defended by various studies, among which those of Tugnait et al , Chrysanthakopoulos et al and Yared et al. [1,24].

Approximately $30.7 \%$ of the patients had already done orthodontic treatment and also had recessions. These values go against several studies that do not support this theory or these values. Other studies support this theory, however we didn't obtain statistical significant differences [7,30,31].

We found that $25.7 \%$ of patients had alcohol habits and presented recessions, $5.9 \%$ smoked and exhibited recessions and $19.8 \%$ had both habits and also presented gingival recessions. In the sample studied, $51.4 \%$ had some kind of habit and gingival recession. We can see that authors like Warnakulasuriya et al. and Johnson and Khocht et al. were right when describing the possible correlation between the use of tobacco and alcohol and the development of recessions $[32,33]$.

\section{CONCLUSIONS}

There are few studies about this subject in Portugal, and this one is presented as a valuable contribution to the existing global studies because of the importance that the presence of gingival recession can affect the oral health of an individual due to complications that may arise such as tooth hypersensitivity, aesthetic implications, the development of root dental caries, as well as erosion and abrasion of the tooth. The majority of the sample already had suitable oral health behaviors; however, there are relevant behaviors that need to be changed, such as the need for understanding the proper brushing movements and techniques in order to avoid a higher risk of gingival recession development.

Therefore, we recommend the implementation of oral health education programmes in order to instruct the population how to brush properly, avoid the accumulation of plaque, the importance of cessation of smoking and/ or alcoholics habits when they exist and the importance of periodic dental appointments so that the dentist can prevent all the predisposing factors for the development of recessions.
This study presents an enormous potential in oral health and even in general health, however, for future studies, a more representative sample of the population is required.

\section{ACKNOWLEDGMENTS}

The authors are deeply indebted with the patients that participated in the development of this study and data collection. We also thank the professors, students and clinic staff of the University Clinic of the Portuguese Catholic University of Viseu, Portugal, for the participation and important contribution in this study.

\section{REFERENCES}

1. Sala Emili, GP. Odontología preventiva y comunitaria. $3^{\text {rd }}$ ed. Masson, S.A.; 2005

2. Martins, M. A promoção da saúde: percursos e paradigma. Ver Saúde Amato Lusitano. 2005; 9(22):42-6.

3. Ordem dos Médicos Dentistas. Plano nacional de saúde 2011-2016 estratégia de saúde oral em Portugal - um conceito de transversalidade que urge implementar (projecto conceptual). 2011; 2-29.

4. Slade GD. Measuring oral health and quality of life. Department of Dental Ecology, School of Dentistry, University of North Carolina. 1997.

5. Kimbrough VJ, Karen $\mathrm{H}$. Oral health education. $1^{\text {st }}$ ed. Prentice Hall; 2006.

6. Petersen PE, Kandelman D, Arpin S, Ogawa H. Global oral health of older people - Call for public health action. Community Dent. Health. 2010; 27(2):257-68

7. Shinkai Ro, Cury A. O papel da odontologia na equipe interdisciplinar: contribuindo para a atenção integral ao idoso. Cad. Saúde Pública. 2000; 16(4):1099-109

8. World Health Organization. Oral health. Fact sheet. 2007:11-2

9. Harris NO, García-Godoy F. Primary preventive dentistry. $6^{\text {th }}$ ed. Prentice Hall; 2004.

10. Rateitschak KH, Rateitschak EM, Wolf HF, Hassell TM. Colour Atlas of Periodontology. $3^{\text {rd }}$ ed. Thieme; 2005

11. Clerehugh V, Tugnait A, Genco R. Periodontology at a glance. $1^{\text {st }}$ ed. Wiley-Blackwell; 2009

12. Lindhe J, Niklaus L, Karring T. Clinical periodontology and implant denstistry. 5a ed. Blackwell Munksgaard; 2008.

13. Mueller HP. Periodontology - The essentials. $1^{\text {st }}$ ed. Thieme; 2005.

14. Newman MG, Takei HH, Carranza FA. Carranza's Clinical Periodontology. $9^{\text {th }}$ ed. Saunders; 2002.

15. Rose L, Genco R. Periodontal Medicine. $1^{\text {st }}$ ed. B.C. Decker Corp. 2000

16. Panagakos F, Davies R. Gingival diseases - their aetiology, prevention and treatment. $1^{\text {st }}$ ed. InTesh; 2011.

17. Tugnait A. Gingival recession - its significance and management. J. Dent. $2001 ; 29(6): 381-94$

18. Chrysanthakopoulos NA. Aetiology and severity of gingival recession in an adult population sample in Greece. Dent. Res. J. 2011;8(2):64-70.

19. Marini MG, Greghi SLA, Passanezi E, Sant'ana ACP. Gingival recession: prevalence, extension and severity in adults. J Appl Oral Sci. 2004; 12(3):250-5.

20. Kassab M, Cohen $\mathrm{R}$. The etiology and prevalence of gingival recession J Am Dent Assoc. 2003;134(2): 220-5

21. Lafzi A, Abolfazli N. Assessment of the etiologic factors of gingival recession in a group of patients in Northwest Iran. J Dent Res Dent Clin Dent Prospects. 2009;3(3):90-3. https://doi.org/10.5681/joddd. 2009.023

22. Slutzkey S, Levin L. Gingival recession in young adults: occurrence, severity, and relationship to past orthodontic treatment and oral piercing. Am. J. Orthod. Dentofac. Orthop. 2008;134(5):652-6. https://doi. org/10.1016/j.ajodo.2007.02.054

23. Mahajan A. Mahajan's modification of the miller's classification for gingival recession. Dent. Hypotheses. 2010;1(2):45-50. https://doi. org/10.4103/0972-124X.128198

24. Ravishankar Y, Srinivas K. Sharma S. Management of black triangles and gingival recession: a prosthetic approach. Indian J. Dent. Sci. 2012; 4(1):141-5. 
25. Alghamdi H, Babay N, Sukumaran A. Surgical management of gingival recession: A clinical update. Saudi Dent. J. King Saud University; 2009; 21(2):83-94. https://doi.org/10.1016/j.sdentj.2009.07.006

26. Smith R. Gingival recession reappraisal of an enigmatic condition and a new index for monitoring. J. Clin. Periodontol. 1997;24(3):201-5.

27. Furlan L, Sallum A, Sallum E, Junior F. Incidência de recessão gengival e hipersensibilidade dentinária na clínica de graduação da FOP-UNICAMP. Rev. Periodontia. 2008;18:53-61.

28. Mumghamba EGS, Honkala S, Honkala E, Manji KP. Gingival recession, oral hygiene and associated factors among Tanzanian women. East Afr. Med. J. 2009; 86(3):125-32.

29. Chute M, Gunjikar T, Lobo T, Pol S. Dentine hypersensitivity: the distribution of recession, sensitivity and plaque. J. Indian Dent. Assoc. 2012;6:139-41.

30. Bartold PM. Dentinal hypersensitivity: a review. Aust. Dent. J. 2006; 51(3):212-8
31. Rutsatz C, Baumhardt SG, Feldens CA, Rösing CK, Grazziotin-Soares $\mathrm{R}$, Barletta FB. Response of pulp sensibility test is strongly influenced by periodontal attachment loss and gingival recession. J. Endod. 2012 38(5):580-3. https://doi.org/10.1016/j.joen.2012.01.011

32. Patel M, Nixon PJ, Chan MFW-Y. Gingival recession: part 3. Surgical management using free grafts and guided tissue regeneration. $\mathrm{Br}$ Dent. J. [Internet]. 2011;211(8):353-8. https://doi.org/10.1038/sj.bdj. 2011.861

33. Zalkind M, Hochman N. Alternative method of conservative esthetic treatment for gingival recession. J. Prosthet. Dent. 1997;77(6):561-3 